Elsevier required licence: (C) <2019>. This manuscript version is made available under the CC-BY-NCND 4.0 license http://creativecommons.org/licenses/by-nc-nd/4.0/

The definitive publisher version is available online at

[https://www.sciencedirect.com/science/article/pii/S0960852419305814?via\%3Dihub] 


\title{
Biological denitrification in an anoxic sequencing batch biofilm reactor: Performance evaluation, nitrous oxide emission and microbial community
}

\author{
Xiangwei Ding ${ }^{\mathrm{a}}$, Dong Wei ${ }^{\mathrm{a}, *}$, Wenshan Guo ${ }^{\mathrm{b}}$, Ben Wang ${ }^{\mathrm{a}}$, Zijun Meng ${ }^{\mathrm{a}}$, Rui Feng ${ }^{\mathrm{a}}$, Bin $\mathrm{Du}^{\mathrm{a}}$, \\ Qin $\mathrm{Wei}^{\mathrm{c}}$ \\ a School of Water Conservancy and Environment, University of Jinan, Jinan 250022, PR China \\ $\mathrm{b}$ School of Civil and Environmental Engineering, University of Technology Sydney, Broadway, NSW 2007, Australia \\ ${ }^{c}$ Key Laboratory of Interfacial Reaction \& Sensing Analysis in Universities of Shandong, School of Chemistry and Chemical \\ Engineering, University of Jinan, Jinan 250022, PR China \\ * Corresponding author. \\ E-mail address: weidong506@163.com (D.Wei).
}

Keywords: Biological denitrification Biofilm; Soluble microbial products (SMP); Nitrous oxide $\left(\mathrm{N}_{2} \mathrm{O}\right)$; Highthroughput sequencing

\section{A B S T R A C T}

The present study evaluated the performance of biological denitrification in an anoxic sequencing batch biofilm reactor (ASBBR) and its nitrous oxide $\left(\mathrm{N}_{2} \mathrm{O}\right)$ emission. After 90 days operation, the effluent chemical oxygen demand and total nitrogen removal efficiencies high of $94.8 \%$ and $95.0 \%$, respectively. Both polysaccharides and protein contents were reduced in bound EPS (TB-EPS) and loosely bound EPS (LB-EPS) after biofilm formation. According to typical cycle, $\mathrm{N}_{2} \mathrm{O}$ release rate was related to the free nitrous acid (FNA) concentration with the maximum value of $3.88 \mu \mathrm{g} / \mathrm{min}$ and total conversion rate of $1.27 \%$. Two components were identified from EEM-PARAFAC model in soluble microbial products (SMP). Protein-like substances for component 1 changed significantly in denitrification process, whereas humic-like and fulvic acid-like substances for component 2 remained relatively stable. High-throughput sequencing results showed that Lysobacter, Tolumonas and Thauera were the dominant genera, indicating the co-existence of autotrophic and heterotrophic denitrifiers in ASBBR.

\section{Introduction}

Nowadays, nitrate contamination from water resources is attracted increasing attention with the rapid development of industrial and agricultural (Jan Willem et al., 2013). Nitrate is potentially reduced to nitrite that could combine with haemoglobin to form methaemoglobin within the human body, which can be fatal to neonates (Ghafari et al., 2008). It has been reported that the nitrate concentration in most rivers 
in populated region are seriously exceeded the maximum level (10 mg/ L) allowed by the Global Environment Monitoring System database (He et al., 2011). Moreover, discharge of industrial wastewater and excessive $\mathrm{N}$ fertilizer application might be expected to lead to nitrate pollution of groundwater (Li et al., 2016). In most wastewater treatment plants (WWTPs), the lack of sufficient carbon source in wastewater treatment can also lead to accumulation of nitrate and nitrite in the effluent (Pott and Fohrer, 2017).

For the treatment of nitrate containing wastewater, reverse osmosis, ion-exchange, active metal reduction, catalysis and biological denitrification are the most widely applied methods. Biological denitrification is the process that nitrate and nitrite are reduced to gaseous nitrogen $\left(\mathrm{N}_{2}\right)$ through a series of biochemical processes by microbial metabolism, which is considered to be an efficient and environmentfriendly technique of nitrogen removal (Haugen et al., 2002). However, activated sludge system may be unstable under the impact of external environment, and the nitrogen removal efficiency is hard to maintain at a high level. In comparison with traditional suspended-growth activated sludge, biofilm has advantages of low land requirement, great impact resistance to toxicity, easy to achieve solid-liquid separation and no sludge backflow. Till now, biofilm has been applied for treating various low-concentration wastewaters by using different types of reactors (Rodgers et al., 2003).

It is reported that $\mathrm{N}_{2} \mathrm{O}$ emission is associated with autotrophic nitrification and heterotrophic denitrification in biological wastewater treatment (Wunderlin et al., 2012). Analysis of literature favoring $\mathrm{N}_{2} \mathrm{O}$ production in nitrification and denitrification stages are identified: low dissolved oxygen (DO), increased nitrite concentrations, rapidly changing conditions or low ratio of chemical oxygen demand COD to nitrate (Kampschreur et al., 2009). In denitrification process, the electrons were originally devoted by organic carbon compounds and then transferred to the nitrogen oxide reductases, including nitrate reductase (NAR), nitrite reductase (NIR), nitric oxide reductase (NOR) and nitrous oxide reductase $\left(\mathrm{N}_{2} \mathrm{OR}\right)$, to reduce the corresponding nitrogen oxides. Nevertheless, $\mathrm{N}_{2} \mathrm{O}$ could accumulate and emit to atmosphere due to the incomplete denitrification caused by inadequate operational conditions (Wang et al., 2018). The mechanisms of $\mathrm{N}_{2} \mathrm{O}$ emissions from nitrifying activated sludge have been widely investigated, while little information could be found in the heterotrophic denitrification biofilm under anoxic conditions. The investigation on $\mathrm{N}_{2} \mathrm{O}$ production would provide a theoretical basis for controlling the emission of greenhouse gases in biological denitrification process.

Generally, nitrate removal efficiency in denitrification biofilm is closely related to the content of COD in wastewater. It is important to provide suitable COD as electron donor for nitrate treatment to avoid excessive concentration of organic matter in the effluent. Soluble microbial products (SMP) are regarded as the major component of the effluent COD in many cases (Kunacheva and Stuckey, 2014). SMP are defined as the pool of organic compounds that released into solute from substrate metabolism (Yu et al., 2015). Dong et al. (2018) evaluated the SMP formation from aerobic granular sludge in denitrification process by using spectrometric approaches, implying that SMP production were strongly strengthened by increasing $\mathrm{COD} / \mathrm{N}$ ratio. Although most of SMP can be slowly biodegraded by microorganism, recalcitrant SMP in the effluent is a problem for practical application (Libing and Jianlong, 2013). Therefore, it is significant to investigate the variations of the key components in SMP of biofilm denitrification process.

Based on the above discussion, the achievement and performance evaluation of biological denitrification was investigated in an anoxic sequencing batch biofilm reactor (ASBBR). The release rate of $\mathrm{N}_{2} \mathrm{O}$ in a typical cycle of ASBBR was studied during the stable operation phase. SMP were analyzed by a combination of three-dimensional Excitationemission matrix (3D-EEM), parallel factor analysis (PARAFAC) and Fourier Transform Infrared Spectroscopy (FTIR) after the formation of denitrification biofilm. Microbial community of denitrification biofilm was conducted by using high-throughput sequencing technology. The obtained results could provide useful information about the variations of microbial metabolites and the behaviors of microbial community in biological denitrification biofilm process.

\section{Methods and materials}

\subsection{Experimental system and operation}

The heterotrophic denitrification process was conducted in an ASBBR, which was made of plexiglass (See Supplementary data for more details). The effective volume of the ASBBR was $3.4 \mathrm{~L}(12 \mathrm{~cm}$ in diameter and $30 \mathrm{~cm}$ in height), and the sampling port was set at $25 \%$ of the height. The reactor was operated at a volumetric exchange ratio of $50 \%$ with a cycle of $8 \mathrm{~h}$, resulting in the hydraulic retention time (HRT) was $16 \mathrm{~h}$. Biocarriers (K3 plastic media) were applied as biomass support with a packing rate of $40 \%(\mathrm{v} / \mathrm{v})$. The diameter and height of each carrier were $25 \mathrm{~mm}$ and $12 \mathrm{~mm}$ respectively, and the specific surface area and bulk density were $500 \mathrm{~m}^{2} / \mathrm{m}^{3}$ and $110 \mathrm{~kg} / \mathrm{m}^{3}$, respectively. The synthetic wastewater was prepared in a $60 \mathrm{~L}$ water tank, and pumped into the reactor through a metering pump. A magnetic stirrer was installed at the bottom of the reactor to make the biofilm and wastewater mix thoroughly. The cycle was set at $8 \mathrm{~h}$, including $5 \mathrm{~min}$ of influent, $380 \mathrm{~min}$ of anoxic phase, $30 \mathrm{~min}$ of settling time, $5 \mathrm{~min}$ of effluent and $60 \mathrm{~min}$ of idle time. The biofilm was formed onto the biocarriers after operating for two weeks, the effluent nitrogen concentrations were measured every day in order to determine whether the process was stable. The ASBBR was operated at room temperature $\left(25-27^{\circ} \mathrm{C}\right)$. A time controller was installed to achieve the reactor automatic operation.

\subsection{Synthetic wastewater and seed sludge}

The compositions of synthetic wastewater were as follows: COD (as glucose), $300 \mathrm{mg} / \mathrm{L}$; nitrate (as $\mathrm{KNO}_{3}$ ), $50 \mathrm{mg} / \mathrm{L}$; phosphate (as $\mathrm{K}_{2} \mathrm{HPO}_{4}$ ), $5 \mathrm{mg} / \mathrm{L} ; \mathrm{CaCl}_{2}, 40 \mathrm{mg} / \mathrm{L} ; \mathrm{MgSO}_{4} \cdot 2 \mathrm{H}_{2} \mathrm{O}, 20 \mathrm{mg} / \mathrm{L} ; \mathrm{FeSO}_{4} \cdot 2 \mathrm{H}_{2} \mathrm{O}$, $20 \mathrm{mg} / \mathrm{L}$ and microelement solution $1.0 \mathrm{~mL} / \mathrm{L}$. The influent COD/N was controlled at 6 to ensure the effect of heterotrophic denitrification (Dong et al., 2018). The compositions of the microelement solution were as follows: $\mathrm{H}_{3} \mathrm{BO}_{3} 0.05 \mathrm{~g} / \mathrm{L}, \mathrm{ZnCl}_{2} 0.05 \mathrm{~g} / \mathrm{L}, \mathrm{CuCl}_{2} 0.03 \mathrm{~g} / \mathrm{L}$, $\mathrm{MnSO}_{4} \cdot \mathrm{H}_{2} \mathrm{O} 0.05 \mathrm{~g} / \mathrm{L},\left(\mathrm{NH}_{4}\right)_{6} \mathrm{MoO}_{24} \cdot 4 \mathrm{H}_{2} \mathrm{O} 0.05 \mathrm{~g} / \mathrm{L}, \mathrm{AlCl}_{3} 0.05 \mathrm{~g} / \mathrm{L}$, $\mathrm{CoCl}_{2} \cdot 6 \mathrm{H}_{2} \mathrm{O} 0.05 \mathrm{~g} / \mathrm{L}, \mathrm{NiCl}_{2} 0.05 \mathrm{~g} / \mathrm{L}$. The influent $\mathrm{pH}$ value was normally at 6.8 by adding $\mathrm{NaHCO}_{3}$ and needed no further adjustment. The seed sludge was collected from a lab-scale sequencing batch reactor (SBR), which was operated about two years for treating high ammonianitrogen wastewater. The initial mixed liquid suspended solids (MLSS) of ASBBR was controlled at $3.0 \mathrm{~g} / \mathrm{L}$.

\subsection{EPS, SMP extraction and fluorescent spectra}

A heat extraction method was used to extract the loosely bound EPS (LB-EPS) and tightly bound EPS (TB-EPS) from the seed sludge and biofilm. The sludge suspension was cleaned for three times by centrifuging in a $50-\mathrm{mL}$ tube at $4000 \mathrm{~g}$ for $5 \mathrm{~min}$. The sludge was then resuspended into $15 \mathrm{~mL}$ of $0.05 \% \mathrm{NaCl}$ solution that was pre-heated to $70{ }^{\circ} \mathrm{C}$. The supernatant was regarded as LB-EPS after centrifugation at $4000 \mathrm{~g}$ for $10 \mathrm{~min}$. Heating at $60^{\circ} \mathrm{C}$ for $30 \mathrm{~min}$ after adding $15 \mathrm{~mL} 0.05 \%$ $\mathrm{NaCl}$ solution that was pre-heated to $70^{\circ} \mathrm{C}$, the supernatant was regarded as TB-EPS after centrifugation at $4000 \mathrm{~g}$ for $15 \mathrm{~min}$ ( Li and Yang, 2007). Mixture collected from ASBBR were centrifuged at $4000 \mathrm{rpm}$ and filtrated at $0.45-\mu \mathrm{m}$ membrane filter, the supernatant to represent SMP. 3D-EEM scans of EPS and SMP were made at the emission wavelengths (Em) from $200 \mathrm{~nm}$ to $400 \mathrm{~nm}$ with a $10 \mathrm{~nm}$-increment and at the excitation wavelengths (Ex) from $280 \mathrm{~nm}$ to $550 \mathrm{~nm}$ at $0.5 \mathrm{~nm}$-increments with $5 \mathrm{~nm}$ intervals, keep the scanning speed at $1200 \mathrm{~nm} / \mathrm{min}$ for all the measurements. 


\subsection{Microbial community analysis}

Two samples were collected from the two stages, stage 1 and stage 2 represented the biofilm and the seed sludge. Total genome DNA of the samples were extracted by using cetyltrimethy 1 ammonium bromide/ sodium dodecyl sulfate (CTAB/SDS) method. DNA concentration and purity were monitored on $1 \%$ agarose gels. DNA was diluted to $1 \mathrm{ng} / \mu \mathrm{L}$ in centrifuge tube by using sterile water. The diluted genomic DNA was used as a template on the $16 \mathrm{~S}$ V4 region. Efficient high-fidelity enzyme and bacterial diversity primers 515F (5'-GTGCCAGCMGCCGCGG TAA-3') and 806R (5'-GGACTACHVGGGTWTCTAAT-3') with the barcode were used to amplify the V4 region of $16 \mathrm{~S}$ rDNA gene. Highthroughput sequencing analysis was sent to Novogene Co., LTD (Beijing, China).

\subsection{Analytical methods}

The concentrations of $\mathrm{COD}, \mathrm{NO}_{2}{ }^{-}-\mathrm{N}$ and $\mathrm{NO}_{3}{ }^{-}-\mathrm{N}$ were detected by using UV-Vis spectrophotometry according to the standard methods (APHA, 2005). The polysaccharides (PS) and protein (PRO) contents were determined by using anthrone-sulfuric method and modified Lowry method, respectively (Larson et al., 1986). 3D-EEM spectra were characterized by using a Luminescence spectrometer (LS-55, PerkinElmer Co., USA). FTIR analysis of SMP samples were recorded by using a Perkin-Elmer FTIR spectrometer (United States). Before measurement, SMP samples were freeze-drying at $-60^{\circ} \mathrm{C} . \mathrm{N}_{2} \mathrm{O}$ concentration was measured by using a gas chromatography (7890B, Agilent USA) with an electron capture detector (ECD) and a Poropak Q column. FNA concentration and $\mathrm{N}_{2} \mathrm{O}$ conversion rate were calculated by the following expressions:

$\mathrm{FN} A(\mathrm{mg} / \mathrm{L})=\frac{46}{14} \times \frac{\left[\mathrm{NO}_{2}^{-}-\mathrm{N}\right]}{\exp [-2300 /(273+T)] \times 10^{\mathrm{pH}}}$

$\mathrm{N}_{2} \mathrm{O}-$ Nconversionrate $(\%)=\frac{\text { total }_{2} \mathrm{O}-\text { Nemission }}{\text { totalnitrogen }} \times 100 \%$

\section{Results and discussion}

\subsection{Performance of $A S B B R$}

Fig. 1 showed the performance of nitrogen removal in the ASBBR during the whole experimental period ( 90 days). According to the effluent concentrations of nitrogen compounds, the experiment could be divided into two stages: start-up stage (1-30 days) and steady state stage (31-90 days). In the early stage I (1-10 days), the effluent $\mathrm{NO}_{3}{ }^{-}$$\mathrm{N}$ concentration was averaged at $25 \mathrm{mg} / \mathrm{L}$ after being inoculated with seed sludge, and the maximum $\mathrm{NO}_{2}{ }^{-}-\mathrm{N}$ concentration never exceeded

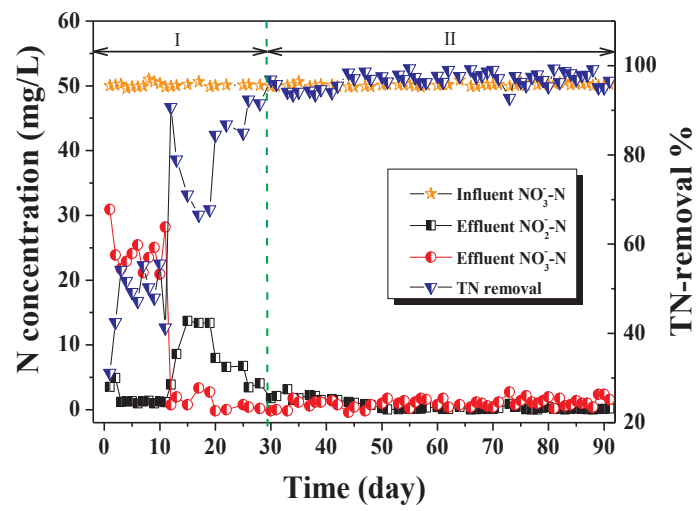

Fig. 1. Performance of nitrogen removal in the ASBBR during the whole operation.
$1.0 \mathrm{mg} / \mathrm{L}$ when fed with $50 \mathrm{mg} / \mathrm{L} \mathrm{NO}_{3}{ }^{-}-\mathrm{N}$. In the following stage I (11-30 days), $\mathrm{NO}_{2}{ }^{-}-\mathrm{N}$ accumulation was observed as the intermediate product with the decrease of $\mathrm{NO}_{3}{ }^{-}-\mathrm{N}$ on the 17 th day. In our previous literature, the ratio of $\mathrm{COD} / \mathrm{NO}_{3}{ }^{-}-\mathrm{N}$ at 6 was sufficient for the complete denitrification (Dong et al., 2018). Therefore, the nitrite accumulation was not caused by organic shortages. Actually, the nitrate in the denitrification system included two kinds of sources, i.e. the residual nitrate in the previous cycle and new nitrate in the influent. Therefore, most of the $\mathrm{NO}_{3}{ }^{-}-\mathrm{N}$ concentration was reduced to $\mathrm{NO}_{2}{ }^{-} \mathrm{N}$ but not continues to $\mathrm{N}_{2}$ because of the increased nitrate loading of the denitrification system. Afterwards, the nitrite reduction was observed due to the enrichment of denitrifying bacteria onto biofilm. It was found that $\mathrm{NO}_{2}{ }^{-}$$\mathrm{N}$ concentration gradually decreased to $1.78 \mathrm{mg} / \mathrm{L}$ on the 30th day, suggesting that the ability to reduce $\mathrm{NO}_{3}{ }^{-}-\mathrm{N}$ to $\mathrm{NO}_{2}{ }^{-} \mathrm{-N}$ was enhanced with the biofilm growth and the enrichment of denitrifying microorganisms on the carrier. Cui et al. (2017) also found that $\mathrm{NO}_{2}{ }^{-} \mathrm{N}$ accumulation may be caused by biofilm growth and different filtration velocities in a denitrifying biofilter.

During the steady state period (Stage II), the effluent $\mathrm{NO}_{3}{ }^{-}-\mathrm{N}$ concentrations were approximately $1.12 \pm 0.66 \mathrm{mg} / \mathrm{L} \quad(n=40)$, whereas the $\mathrm{NO}_{3}{ }^{-}-\mathrm{N}$ removal efficiencies were maintained at relatively high levels (91-99\%) in the ASBBR system. It was found that the average $\mathrm{NO}_{3}{ }^{-}-\mathrm{N}$ removal rate was reached $0.146 \mathrm{~kg} \cdot \mathrm{m}^{-3} \cdot \mathrm{d}^{-1}$ in Stage II, which was two times higher than that of early stage I $\left(0.075 \mathrm{~kg} \cdot \mathrm{m}^{-3} \cdot \mathrm{d}^{-1}\right)$. Since glucose was easy to be degradable, therefore the effluent COD removal efficiency was average at $94.9 \%(n=5)$. The final effluent concentrations of COD $(15.3 \pm 0.5 \mathrm{mg} / \mathrm{L})$ and TN $(1.35 \pm 0.69 \mathrm{mg} / \mathrm{L})$ could satisfy Chinese discharge limits $(<50 \mathrm{mg}$ COD/L and $<15 \mathrm{mg}-\mathrm{TN} / \mathrm{L}$ ). The results of Stage II implied that the ASBBR operated steadily for more than two months, maintained high efficiency for nitrogen removal. Therefore, anoxic biofilm was a steady, efficient and environment friendly approach for heterotrophic denitrification.

\subsection{EPS analysis for denitrification biofilm formation}

EPS are a complex high-molecular-weight mixture of polymers excreted from microorganisms, which are responsible for microbial aggregation, adhesion and biofilm formation through maintaining the three-dimensional structure and scaffolding cells together (Toyofuku et al., 2015). As the main compositions of LB-EPS and TB-EPS, PRO and PS were measured and compared in the seed sludge and denitrification biofilm. As displayed in Table 1, the PRO and PS contents in TB-EPS were significantly higher than those in LB-EPS. PRO contents were 4.16-7.77 times higher than PS contents in both LB-EPS and TB-EPS, which may be attributed to the presence of a large quantity of exoenzymes in seed sludge. Generally, the large amount of EPS secreted by attached microorganisms could serve to enhance microbial adhesion and promote denitrification biofilm formation. Zhang et al. (2019) found that EPS in biofilm increased from 76.3 to $205.3 \mathrm{mg} \mathrm{gVSS}^{-1}$ compared to suspended sludge. However, the opposite tendency was obtained in this study, PS in LB-EPS and TB-EPS after biofilm formation decreased from 1.2 and $5.2 \mathrm{mg} / \mathrm{g}$ to 0.6 and $3.2 \mathrm{mg} / \mathrm{g}$ respectively, and PRO decreased from 5.7 and $40.4 \mathrm{mg} / \mathrm{g}$ to 2.5 and $21.2 \mathrm{mg} / \mathrm{g}$, respectively. The inhibition of PS and PRO productions in biofilm formation

Table 1

Changes in LB-EPS and TB-EPS contents during the ASBBR achievement process.

\begin{tabular}{lllll}
\hline & EPS type & PRO $(\mathrm{mg} / \mathrm{g})$ & PS $(\mathrm{mg} / \mathrm{g})$ & PRO/PS \\
\hline Seed sludge & LB-EPS & 5.7 & 1.2 & 4.75 \\
\multirow{3}{*}{ Biofilm } & TB-EPS & 40.4 & 5.2 & 7.77 \\
& LB-EPS & 2.5 & 0.6 & 4.16 \\
& TB-EPS & 21.2 & 3.2 & 6.63 \\
\hline
\end{tabular}



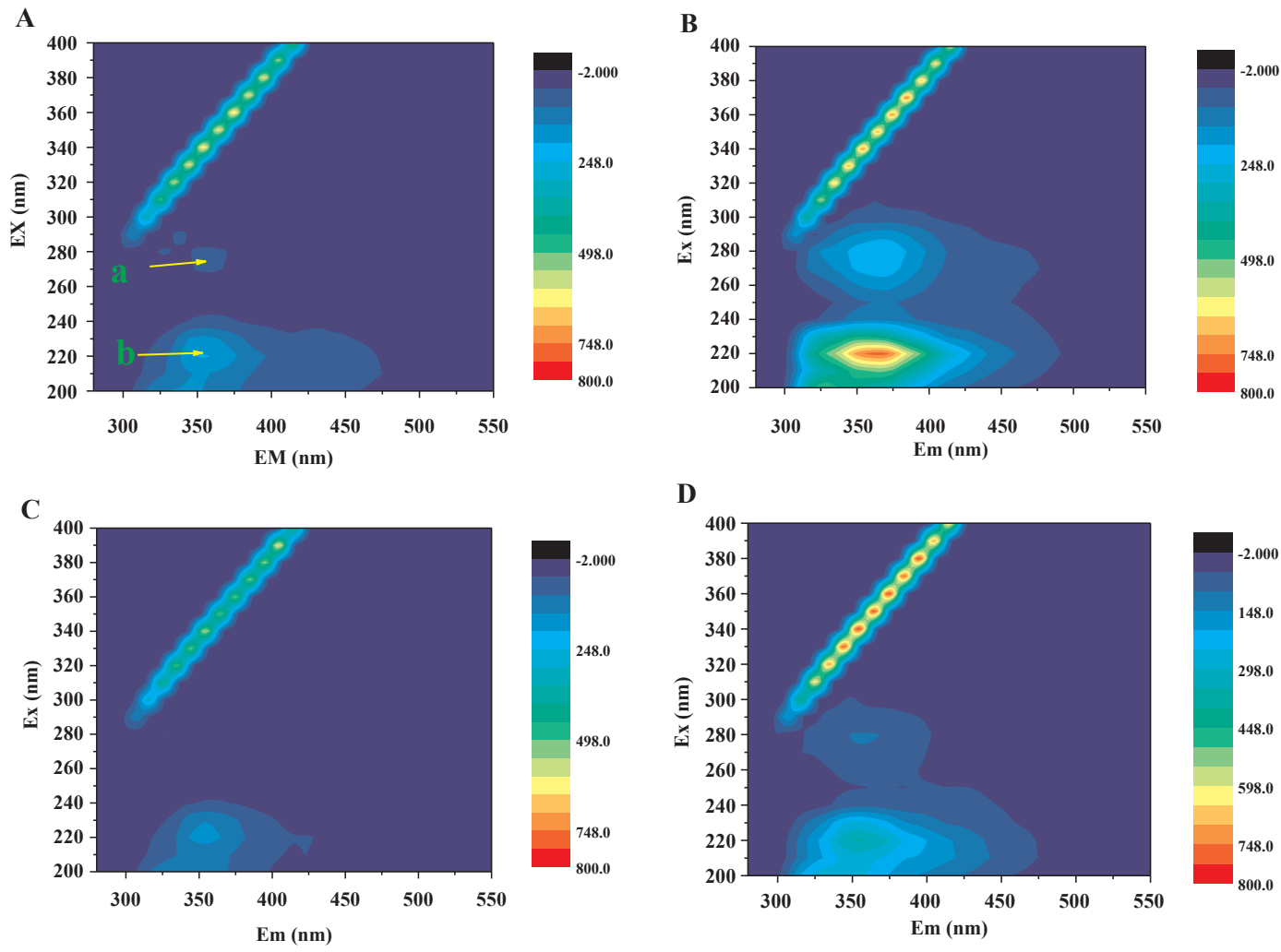

Fig. 2. 3D-EEM fluorescence spectra of LB-EPS and TB-EPS in seed sludge and biofilm: (A) LB-EPS in seed sludge, (B) TB-EPS in seed sludge, (C) LB-EPS in biofilm, (D) TB-EPS in biofilm.
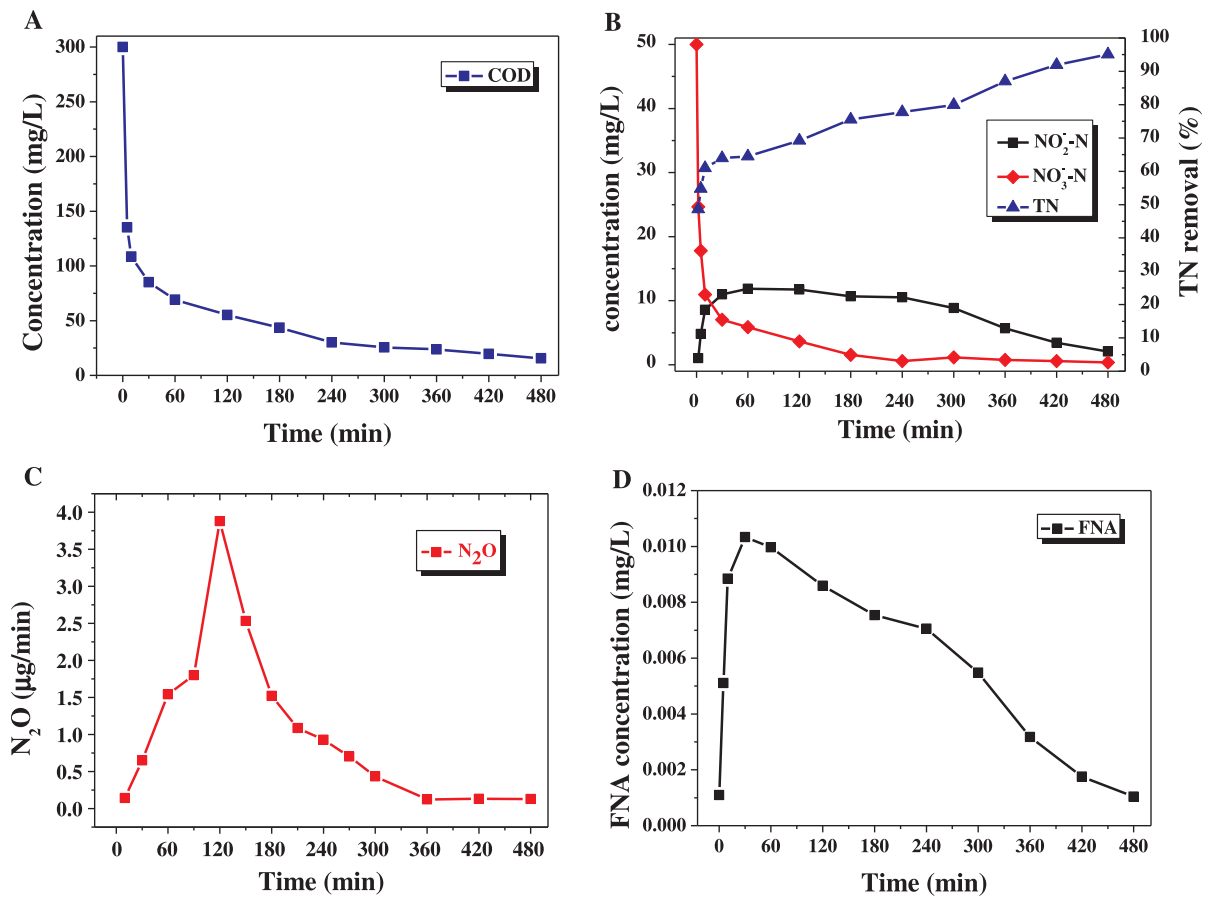

Fig. 3. Variations of nitrogen compounds and system parameters in a typical cycle of ASBBR: (A) COD; (B) Nitrogen compound; (C) $\mathrm{N}_{2} \mathrm{O}$ emission rate; (D) FNA.

was mainly attributed to the external environment, such as feed water characteristics and operational conditions. One reason was that the seed sludge changed from aerobic condition to anoxic condition that caused EPS reduction. Hoa et al. (2003) also observed that EPS production was lower in anaerobic than in aerobic processes. Another reason was that the seed sludge was collected from a SBR that cultured under the high
DO condition (7-8 mg/L) for AGS cultivation, causing that the total EPS content (about $52.5 \mathrm{mg} / \mathrm{g}$ ) was much higher than that of traditional activated sludge in WWTPs $(5.4 \pm 0.4 \mathrm{mg} / \mathrm{g})$ reported by Zhu et al. (2012). In addition, the decrease of TB-EPS content was much higher than that of LB-EPS, suggesting that TB-EPS may be susceptible to the influence of external environment. The ratio of PRO/PS in TB-EPS in 
A

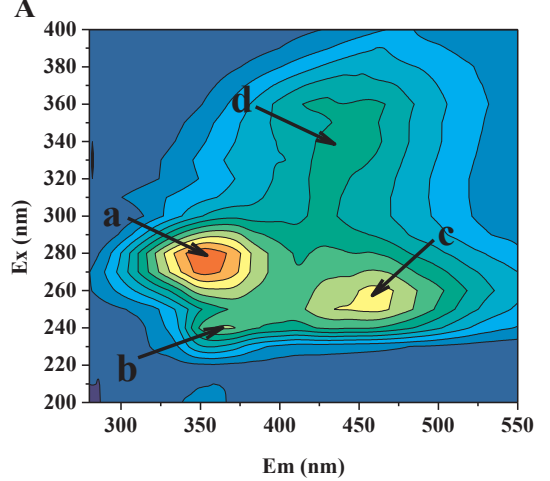

C

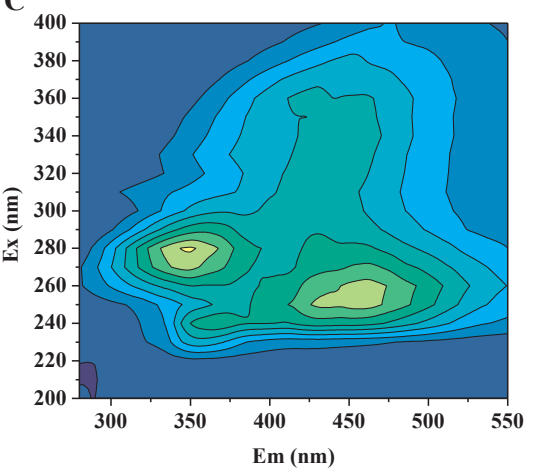

E

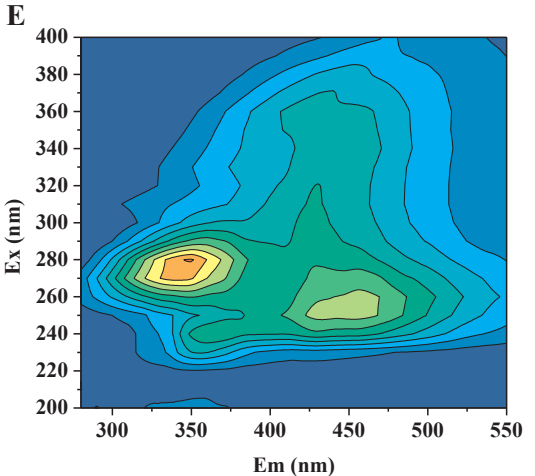

G

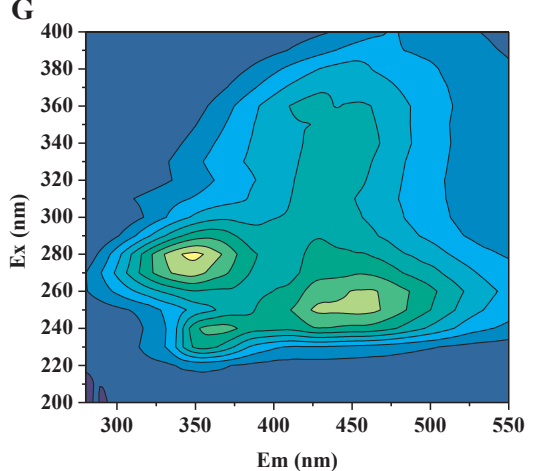

B
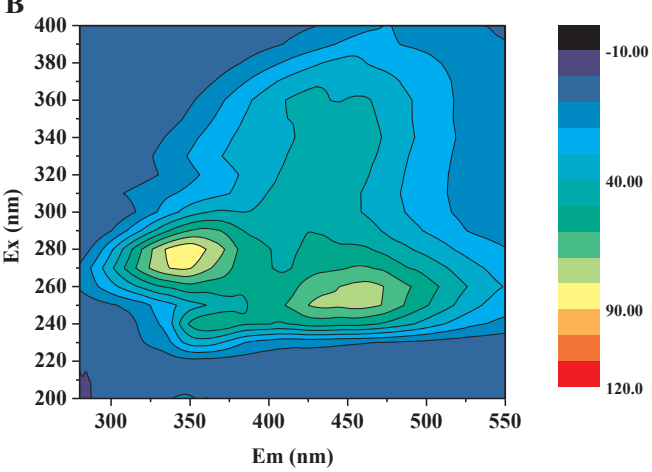

D
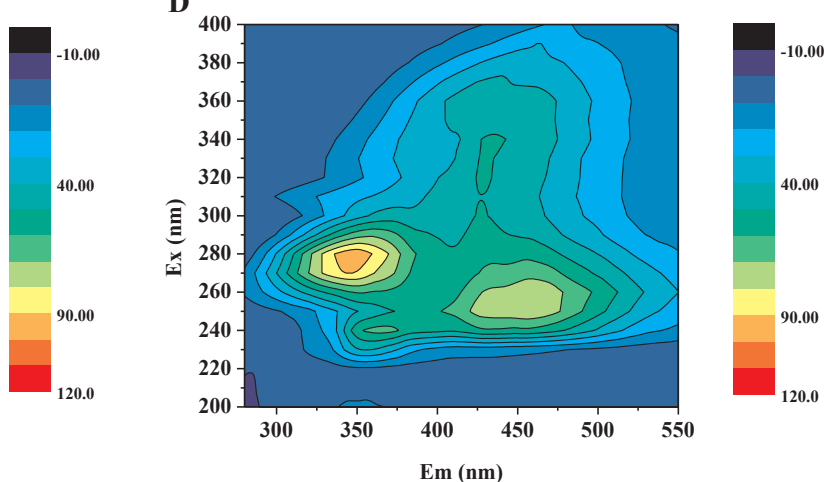

F

F 400

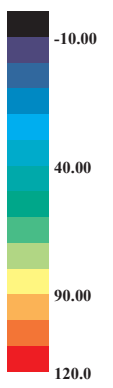

$$
\begin{aligned}
& 380 \\
& 360
\end{aligned}
$$

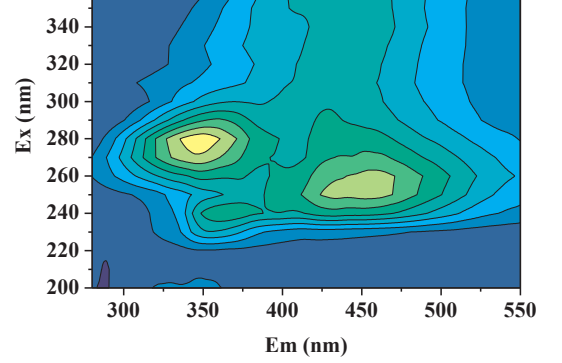

H

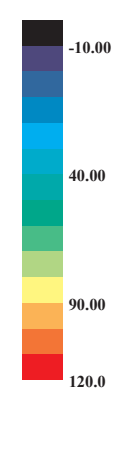

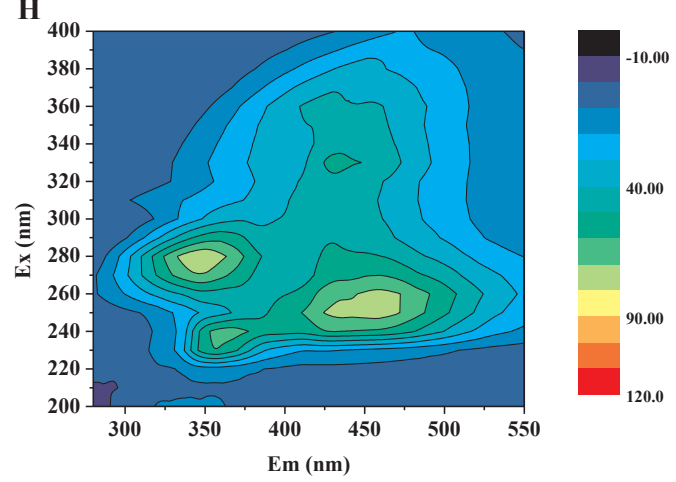

Fig. 4. Fluorescence spectra of SMP samples in a typical cycle of ASBBR: (A) $5 \mathrm{~min}$; (B) $10 \mathrm{~min}$; (C) $30 \mathrm{~min}$; (D) $60 \mathrm{~min}$; (E) $120 \mathrm{~min}$; (F) $240 \mathrm{~min}$; (G) $360 \mathrm{~min}$; (H) $480 \mathrm{~min}$.

the present study was about 6.63 , which was much higher than that of denitrification biofilm (2.7) reported by Wang et al. (2019), and a higher PRO/PS ratio in TB-EPS was beneficial to the stability of biofilm.

3D-EEM was applied to evaluate the changes in chemical compositions of LB-EPS and TB-EPS from seed sludge and biofilm. It was found from Fig. 2 that two major peaks (peak a and peak b) were appeared in each fluorescence spectrum, which were identified at the excitation/ emission (Ex/Em) wavelengths of 260-280/360 and 220-230/380 nm, respectively. Peak a and $\mathrm{b}$ were represented as tryptophan protein-like and aromatic protein-like substances, respectively. After the biofilm was formed, the fluorescence intensity in two peaks of TB-EPS decreased from 247.58 and 773.18 a.u. to 101.54 and 354.62 a.u., respectively. The significantly changed of EPS composition may be in connection with the formation of biofilm, and could also due to 
microorganisms by transferring from aerobic to anoxic environments (Seok-Hwan et al., 2007). In addition, the slightly variation of the peaks positions might due to the change of some enzymes activity in the biosynthesis and metabolism pathway of organic matter, which were needed to be further studied.

\subsection{Water quality and $\mathrm{N}_{2} \mathrm{O}$ emission in a typical ASBBR cycle}

At steady state stage (at day 80 ), the variations of nitrogen compounds and system parameters in a typical cycle of ASBBR were measured and shown in Fig. 3. Throughout of the anoxic process in the cycle, DO was controlled at about $0 \mathrm{mg} / \mathrm{L}, \mathrm{pH}$ value presented gradual upward trend from 6.81 to 7.17 (Supplementary data). As shown in Fig. 3A, the amount of COD decreased sharply from 298.5 to $43.6 \mathrm{mg} / \mathrm{L}$ at $180 \mathrm{~min}$ with the reduction of $\mathrm{NO}_{3}{ }^{-}-\mathrm{N}$, and decreased slowly to $15.6 \mathrm{mg} / \mathrm{L}$ till the end of the reaction. It is observed from Fig. 3B that $\mathrm{NO}_{3}{ }^{-}-\mathrm{N}$ denitrification removal in ASBBR consisted of two phases: a rapid initial decrease from 6 to $30 \mathrm{~min}$, followed by a long period of much slower decline from 30 to $240 \mathrm{~min}$. In the beginning $(0-5 \mathrm{~min})$ of cycle, the $\mathrm{NO}_{3}{ }^{-}-\mathrm{N}$ concentration declined from $50 \mathrm{mg} / \mathrm{L}$ to $24.7 \mathrm{mg} / \mathrm{L}$ due to the dilution process. Afterwards, $\mathrm{NO}_{3}{ }^{-}-\mathrm{N}$ was gradually reduced to $0.9 \mathrm{mg} / \mathrm{L}$ as the electron acceptor for denitrification in the presence of organic matter. In contrast, as one of the intermediates in $\mathrm{NO}_{3}{ }^{-}-\mathrm{N}$ reduction process, $\mathrm{NO}_{2}{ }^{-}-\mathrm{N}$ expressed an increased tendency in the first hour and reached the peak point of $11 \mathrm{mg} / \mathrm{L}$ at $60 \mathrm{~min}$. The reason of $\mathrm{NO}_{2}{ }^{-} \mathrm{N}$ accumulation may be probably because of the $\mathrm{NO}_{2}{ }^{-}-\mathrm{N}$ reduction rate falling behind the rate of $\mathrm{NO}_{3}{ }^{-} \mathrm{N}$ reduction in denitrification process (Wilderer et al., 1987). In the following time (60-480 min), $\mathrm{NO}_{2}{ }^{-}-\mathrm{N}$ declined to about $2 \mathrm{mg} / \mathrm{L}$ at $240 \mathrm{~min}$ and could be removed completely after $480 \mathrm{~min}$. At the end of the cycle, the effluent $\mathrm{NO}_{3}{ }^{-}-\mathrm{N}, \mathrm{NO}_{2}{ }^{-}-\mathrm{N}$ and COD concentrations were 0.38, 2.09 and $15.6 \mathrm{mg} / \mathrm{L}$, respectively, resulting in TN and COD removal efficiencies reached $95.0 \%$ and $94.8 \%$, respectively.

$\mathrm{N}_{2} \mathrm{O}$ can be produced in both nitrification and denitrification processes at lab-scale and full-scale WWTPs. It has been reported that the presence of nitrite, low DO concentration, low $\mathrm{pH}$, and low COD/N ratio can result in $\mathrm{N}_{2} \mathrm{O}$ accumulation during denitrification process (Itokawa et al., 2001). As shown in Fig. 3C, $\mathrm{N}_{2} \mathrm{O}$ release rate dramatically increased to the maximum value of $3.88 \mu \mathrm{g} / \mathrm{min}$ at $120 \mathrm{~min}$, then gradually reduced to $0.13 \mu \mathrm{g} / \mathrm{min}$ at $480 \mathrm{~min}$. It was observed that $\mathrm{N}_{2} \mathrm{O}$ release rate was positively correlated with nitrite concentration (Fig. 3B). The obtained results may be caused that nitrite and $\mathrm{N}_{2} \mathrm{OR}$ would compete for electrons, $\mathrm{N}_{2} \mathrm{O}$ accumulated when the electron flux going to nitrite reduction was higher than that going to $\mathrm{N}_{2} \mathrm{O}$ reduction (Pan et al., 2013). In addition, the competition for electron donors between nitrite and nitrate reductases under co-existence of nitrite and nitrate could also result in $\mathrm{N}_{2} \mathrm{O}$ incomplete reduction (Zhou et al., 2011). As a result, the $\mathrm{N}_{2} \mathrm{O}-\mathrm{N}$ conversion rate was at $1.27 \%$. It was found that the $\mathrm{N}_{2} \mathrm{O}$ emitted from denitrification process was much lower than nitrification process (Hu et al., 2011).

In addition to the effect of nitrite concentration, it is accepted that free nitrous acid (FNA), determined by nitrite concentration and $\mathrm{pH}$, is likely the true inhibitor of $\mathrm{N}_{2} \mathrm{O}$ reduction (Zhou et al., 2008). As shown in Fig. 3D, FNA concentration increased to the maximum value of $9.97 \mu \mathrm{g} / \mathrm{L}$ at $60 \mathrm{~min}$, and decreased to $1.04 \mu \mathrm{g} / \mathrm{L}$ till the end of the cycle. It was observed that $\mathrm{N}_{2} \mathrm{O}$ release rates were releated to the FNA concentrations. Zhou et al. (2008) reported that the $\mathrm{N}_{2} \mathrm{O}$ reduction decreased by $50 \%$ at FNA concentrations of $0.7-1.0 \mu \mathrm{g} \mathrm{HNO}_{2}-\mathrm{N} / \mathrm{L}$ in a denitrifying-enhanced biological phosphorus system, and totally inhibited when FNA concentration was higher than $4 \mu \mathrm{g} \mathrm{HNO}_{2}$-N/L. Yang et al. (2016) also reported that $\mathrm{N}_{2} \mathrm{O}$ accumulation ratio increased from $0.002 \%$ to $0.405 \%$ when the FNA concentration increased from 0.009 to $0.31 \mu \mathrm{g} \mathrm{N} / \mathrm{L}$ in a sulfide-driven autotrophic denitrification. It has been reported that the relative $\mathrm{N}_{2} \mathrm{O}$ reduction rate declined from $60.4 \%$ to $8.2 \%$ when FNA concentration increased from $20.5 \mu \mathrm{g} \mathrm{N} / \mathrm{L}$ to $58.3 \mu \mathrm{g}$ N/L (Yajiao et al., 2018).

\subsection{SMP production of ASBBR system}

\subsection{1. $E E M$}

The SMP samples in a typical ASBBR cycle were collected and measured by using 3D-EEM spectra. It was found from Fig. 4A that four main peaks (Peak a, Peak b, and Peak c, Peak d) were identified at Ex/ Em wavelengths of 280/350, 240/360, 260/480 and 340/445 nm in the first $5 \mathrm{~min}$, respectively, which were regarded as tryptophan proteinlike, aromatic protein-like, fulvic acid-like and humic-like substances (Zichao et al., 2013). In initial influent process, the abundant nitrate and organic matter stimulated the release of SMP, and therefore the fluorescence intensities of the four peaks were high of 108.5, 71.6, 83.2 and 55.2 a.u., respectively. After a cycle of operation, the fluorescence intensities of protein-like substances significantly changed and the other two peaks did not change obviously, indicating that protein-like substances played a critical part in denitrification process. Previous literature has been well reported that protein-like substances are easily bio-degradable, whereas humic-like substances are non-biodegradable (Wang et al., 2009).

\subsubsection{PARAFAC analysis}

The combination of PARAFAC analysis and 3D-EEM analysis is widely used in SMP qualitative analysis of wastewater treatment process. It can decompose fluorescence signals into relatively independent fluorescent components, thus solving the problem of overlapping fluorescent regions (Ishii and Boyer, 2012). As shown in Fig. 5A and B, two fluorescence components (1 and 2) of SMP samples were identified by PARAFAC based on EEM spectra. There are two main peaks in component 1 at Ex/Em of 275/350 nm and 240/350 nm, representing the existence of tryptophan protein-like substances and aromatic protein-like substances. By contrast, two peaks in component 2 at Ex/Em of $340 / 440 \mathrm{~nm}$ and $250 / 440 \mathrm{~nm}$ indicated the presence of humic-like and fulvic acid-like substances, respectively (Phong and Jin, 2015).

As shown in Fig. 5C, PARAFAC model provided the relative scores of the two fluorescent components that were related to their changed concentrations in the EEM dataset. Generally, the production of SMP existed in the whole denitrification process due to the microbial metabolism. However, it was found that the fluorescence intensity scores of the component 1 decreased from 0.42 to 0.31 , then increased to 0.39 and decreased to 0.31 at the end of the typical cycle. In contrast, the intensity scores of component 2 remained relatively stable. In 5-60 min, protein-like substances (component 1) may be utilized as organic carbon source for nitrate reduction, thus the scores showed a downward tendency. Yang et al. (2017) also observed that SMP can be regarded as newly generated organic carbon source as electron donor for anoxic denitrification. In $60-180 \mathrm{~min}$, the increased scores of component 1 suggested that the effect of SMP production was higher than that of consumption with the nitrate reduction. Moreover, SMP could also be released from microorganisms in activated sludge or biofilm system to relieve environmental stress (Aquino and Stuckey, 2004). Therefore, more SMP may be formed to relieve nitrite stress in the initial denitrification process. Afterwards, the reduction of nitrite by denitrifying bacteria may lead to protein-like substances were utilized and therefore the scores decreased till the end of the cycle.

\subsubsection{FTIR}

The effect of denitrification on the chemical composition and major functional groups of SMP were analyzed by using FTIR spectrum. FTIR spectra of SMP extracted at 10, 60, 240 and 480 min were shown in supplementary data. Four obvious peaks in SMP were observed. The absorption peak at $3200-3600 \mathrm{~cm}^{-1}$ suggested the presence of hydroxyl from PS and amino group from PRO. As for the peak at approximate $1641-1651 \mathrm{~cm}^{-1}$ region was corresponded to $\mathrm{C}=\mathrm{C}$ (of the aromatic hydrocarbons) stretching vibrations of aromatic proteins and $\mathrm{C}=\mathrm{O}$ vibrations of amides, which were closely related to bio-flocculation and the formation of biofilm. The peak at $1400 \mathrm{~cm}^{-1}$ was caused 

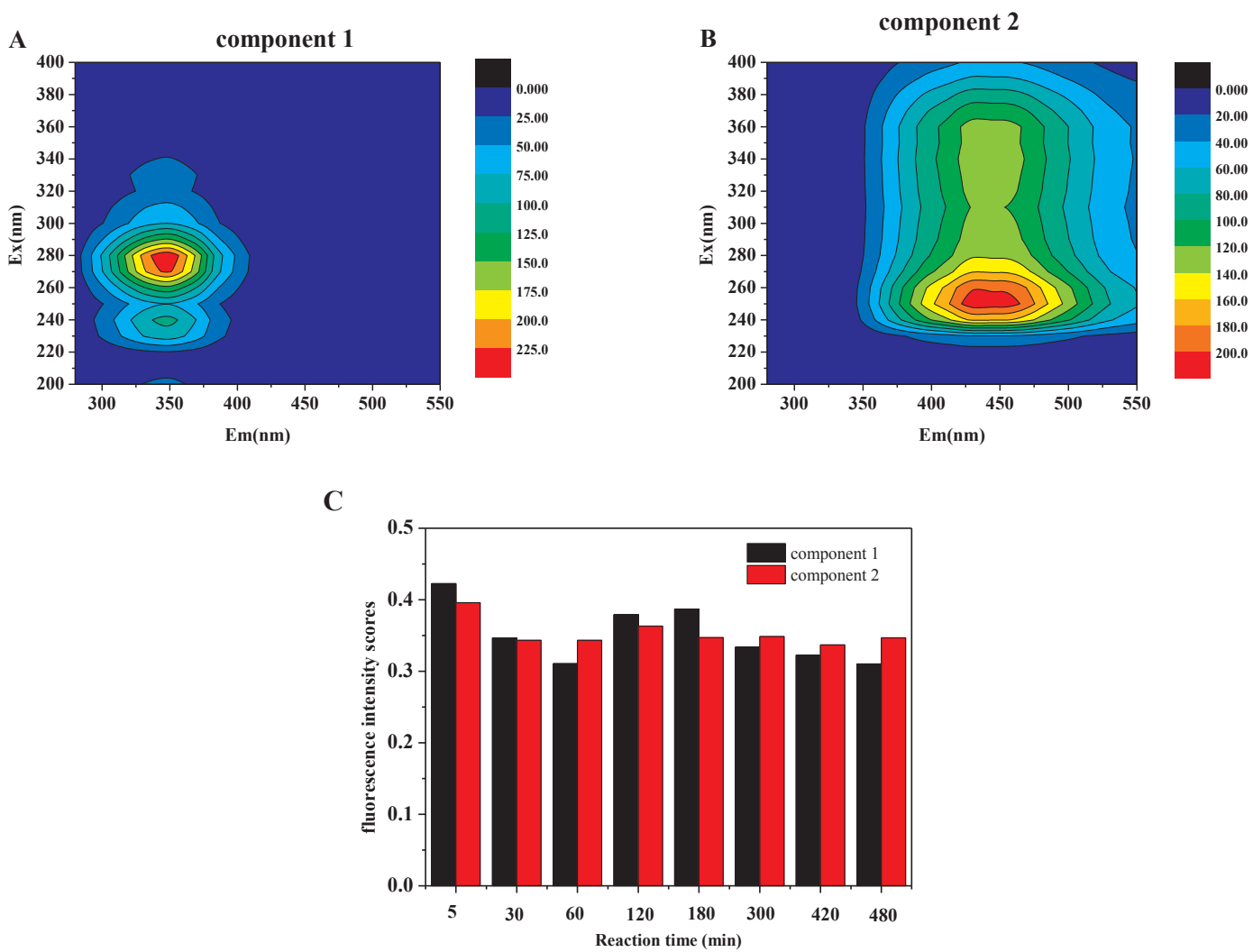

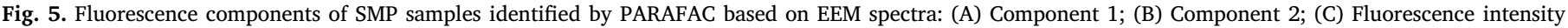
scores of two PARAFAC-derived components.

by - COO- symmetric stretching vibration of deprotonated carboxyl group in aspartic acid. Peak at approximate $619-621 \mathrm{~cm}^{-1}$ was associated with the unsaturated bonds in the sample (Park et al., 2005).

\subsection{Microbial community structure analysis}

Microbial community changes and characteristics during biofilm formation were evaluated by using High-throughput sequencing analysis of $16 \mathrm{~S}$ rRNA amplicon technology. The phylogenetic characteristics of the bacterial communities were studied by comparing the relative abundances. As shown in Fig. 6A, Proteobacteria was the most abundant phylum after biofilm formation, accounting for $75.21 \%$ of total effective bacterial sequences in biofilm (stage 1). The following phyla were Bacteroidetes, Planctomycetes, Chloroflexi and Acidobacteria. Compared with the seed sludge (stage 2), the abundance of Proteobacteria, Planctomycetes and Firmicutes increased from 46.55\%, 0.98\%, and $0.68 \%$ to $75.21 \%, 3.0 \%$ and $1.59 \%$, respectively. Proteobacteria and Planctomycetes were commonly associated with biological nitrogen removal processes (Lei et al., 2016). Firmicutes can produce spores that resist dehydration and other extreme environments, which was closely related to the formation of biofilm (Etienne et al., 2013). Moreover, the proportions of Bacteroidetes, Chloroflexi and Actinobacteria were maintained at relative stable levels. It was accepted that Bacteroidetes was related to denitrification process and also can contribute to the degradation of more recalcitrant compounds that may accumulate in biofilms (Gabarró et al., 2013).

It was found from Fig. 6B that Gammaproteobacteria, Bacteroidia, Alphaproteobacteria and Deltaproteobacteria were detected as dominant classes in two kinds of samples. The total proportions of four corresponding classes were $87.3 \%$ and $60.92 \%$ in biofilm (stage 1 ) and seed sludge (stage 2), respectively. Detailed, the proportions of Gammaproteobacteria and Alphaproteobacteria in biofilm increased by $21.08 \%$ and $8.38 \%$. It was reported that Gammaproteobacteria and Alphaproteobacteria had denitrifying abilities for nitrogen removal in a submerged biofilm membrane bioreactor by adding sponge and biodegradable PBS carrier (Han et al., 2018). Moreover, Alphaproteobacteria was capable of denitrifying $\mathrm{N}_{2} \mathrm{O}$ to $\mathrm{N}_{2}$ (Gabarró et al., 2014). Other literature has been reported that Deltaproteobacteria make up a significant proportion of $\mathrm{N}_{2} \mathrm{O}$-reducing community in different conditions (Jones et al., 2013).

The differences in genera level of bacteria among the two samples were displayed in Fig. 6C. A top 100 genera were identified from biofilm and seed sludge to characterize the composition of bacterial community. It was obvious that the proportions of Lysobacter, Tolumonas and Thauera in seed sludge and biofilm were increased by $4.23 \%$ $15.66 \%$ and $3.55 \%$, respectively. Lysobacter is possibly of facultative autotrophic denitrifiers (Xu et al., 2015). Tolumonas may produce electrons donors for denitrifiers to indirectly contribute to denitrification, which was commonly identified in activated sludge and freshwater lake sediment (Saia et al., 2015). Moreover, the relative abundances of Tolumonas increased in an aerobic granular sludge membrane bioreactor, which were speculated to be the functional bacteria for degrading antibacterial and anti-inflammatory organic matter (Wang et al., 2016). It was noting that the abundance of Denitratisoma decreased from $4.97 \%$ to $0.75 \%$ in anoxic biofilm community, which may be influenced by sludge size distribution or biofilm thickness (Liu et al., 2017).

\section{Conclusion}

In summary, high-efficient nitrogen removal was achieved in an anoxic biofilm denitrification system. LB-EPS and TB-EPS contents decreased after biofilm formation. 3D-EEM showed that protein-like, fulvic acid-like and humic-like substances were identified in SMP, and the fluorescence intensities changed significantly with reaction time during one typical cycle. $\mathrm{N}_{2} \mathrm{O}$ release rate varied with the variation of FNA concentration. Microbial community structure analysis showed that Lysobacter, Tolumonas and Thauera were the dominant genera that were increased by $4.23 \% 15.66 \%$ and $3.55 \%$ after biofilm formation. 

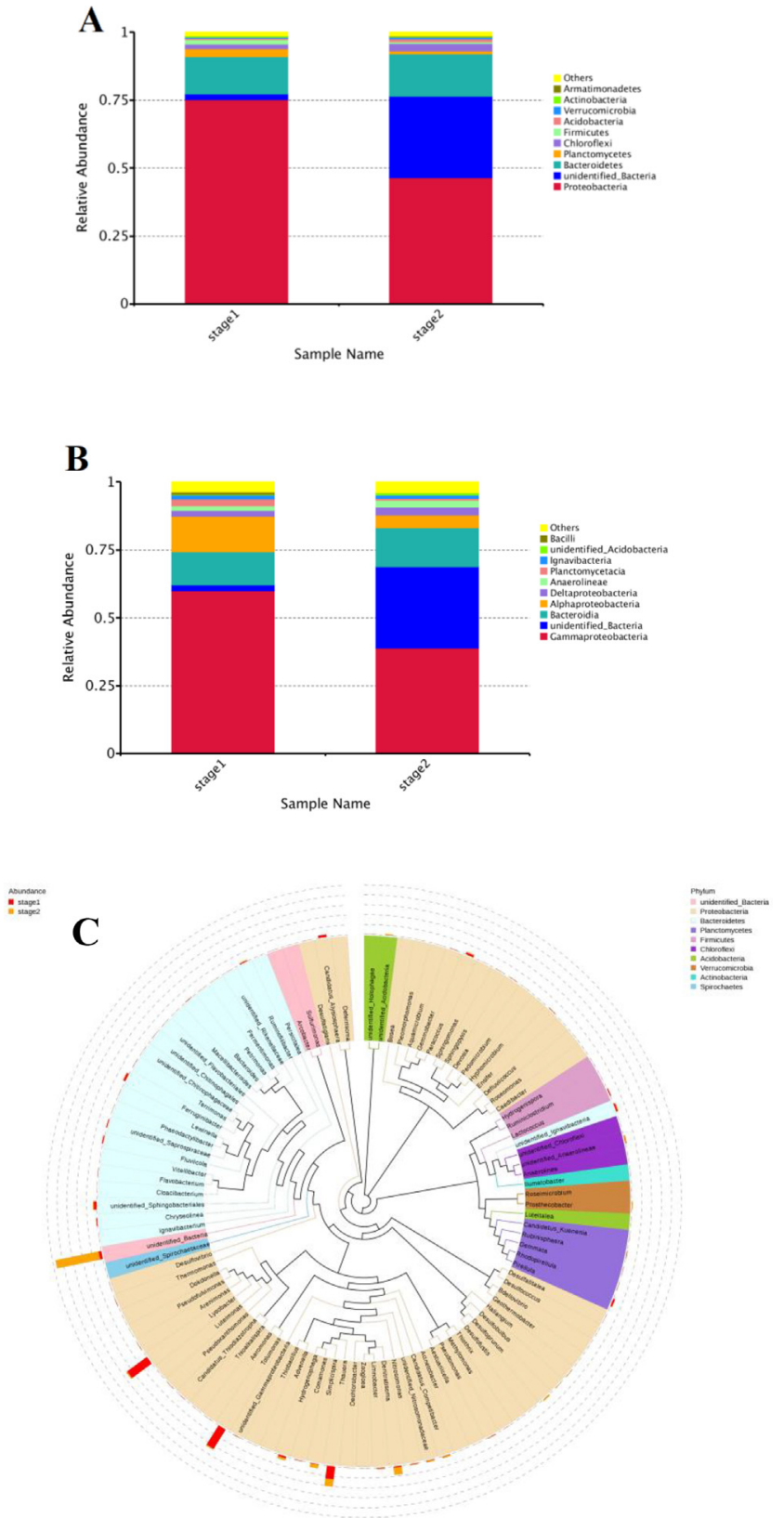

Fig. 6. Taxonomic classification of the bacterial communities of (A) phylum levels, (B) class levels and (C) genus levels (Biofilm sample, stage 1; Seed sludge sample, stage 2).

\section{Acknowledgements}

This study was supported by National Natural Science Foundation of China (21777056), the Key Research and Development Plan of Shandong Province (2018GSF117027), Natural Science Foundation of Shandong Province (ZR201702070162), and QW thanks the Special Foundation for the Taishan Scholar Professorship of Shandong Province and UJN (No. ts20130937).

\section{Appendix A. Supplementary data}

Supplementary data to this article can be found online at https:// doi.org/10.1016/j.biortech.2019.121359.

\section{References}

APHA, 2005. Standard Methods for the Examination of Water and Wastewater. Washington, DC, USA.

Aquino, S.F., Stuckey, D.C., 2004. Soluble microbial products formation in anaerobic chemostats in the presence of toxic compounds. Water Res. 38, 255-266.

Cui, B., Liu, X., Yang, Q., Li, J., Zhou, X., Peng, Y., 2017. Achieving partial denitrification through control of biofilm structure during biofilm growth in denitrifying biofilter.

Bioresour. Technol. 238, 223-231.

Dong, H., Wei, D., Wei, J., Han, F., Yan, T., Khan, M.S., Du, B., Wei, Q., 2018. Qualitative and quantitative spectrometric evaluation of soluble microbial products formation in aerobic granular sludge system treating nitrate wastewater. Bioproc. Biosyst. Eng. 41, $1-10$.

Etienne, Y., Lawrence, J.R., Sylvie, S., Roy, J.L., Swerhone, G.D.W., Korber, D.R., Greer, C.W., 2013. Aerobic biofilms grown from athabasca watershed sediments are in hibited by increasing concentrations of bituminous compounds. Appl. Environ. Microbiol. 79, 7398-7412.

Gabarró, J., González-Cárcamo, P., Ruscalleda, M., Ganigué, R., Gich, F., Balaguer, M., Colprim, J., 2014. Anoxic phases are the main $\mathrm{N}_{2} \mathrm{O}$ contributor in partial nitritation reactors treating high nitrogen loads with alternate aeration. Bioresour. Technol. 163, 92-99.

Gabarró, J., Hernández-del Amo, E., Gich, F., Ruscalleda, M., Balaguer, M., Colprim, J., 2013. Nitrous oxide reduction genetic potential from the microbial community of an intermittently aerated partial nitritation SBR treating mature landfill leachate. Water Res. 47, 7066-7077.

Ghafari, S., Hasan, M., Aroua, M.K., 2008. Bio-electrochemical removal of nitrate from water and wastewater - a review. Bioresour. Technol. 99, 3965-3974.

Han, F., Ye, W., Wei, D., Xu, W., Du, B., Wei, Q., 2018. Simultaneous nitrification-denitrification and membrane fouling alleviation in a submerged biofilm membrane bioreactor with coupling of sponge and biodegradable PBS carrier. Bioresour. Technol. 270, 156-165.

Haugen, K.S., Semmens, M.J., Novak, P.J., 2002. A novel in situ technology for the treatment of nitrate contaminated groundwater. Water Res. 36, 3497-3506.

He, B., Kanae, S., Oki, T., Hirabayashi, Y., Yamashiki, Y., Takara, K., 2011. Assessment of global nitrogen pollution in rivers using an integrated biogeochemical modeling framework. Water Res. 45, 2573-2586.

Hoa, P., Nair, L., Visvanathan, C., 2003. The effect of nutrients on extracellular polymeric substance production and its influence on sludge properties. Water SA 29, 437-442. Hu, Z., Zhang, J., Li, S., Wang, J., Zhang, T., 2011. Effect of anoxic/aerobic phase fraction on $\mathrm{N}_{2} \mathrm{O}$ emission in a sequencing batch reactor under low temperature. Bioresour. Technol. 102, 5486-5491.

Ishii, S.K.L., Boyer, T.H., 2012. Behavior of reoccurring PARAFAC components in fluorescent dissolved organic matter in natural and engineered systems: a critical review. Environ. Sci. Technol. 46, 2006-2017.

Itokawa, H., Hanaki, K., Matsuo, T., 2001. Nitrous oxide production in high-loading biological nitrogen removal process under low cod/n ratio condition. Water Res. 35, 657-664.

Jan Willem, E., Galloway, J.N., Sybil, S., Albert, B., Dise, N.B., Petrescu, A.M.R., Leach, A.M., Wim, D.V., 2013. Consequences of human modification of the global nitrogen cycle. Philos. Trans. Res. Soc. B 368, 20130116.

Jones, C.M., Graf, D.R.H., David, B., Laurent, P., Sara, H., 2013. The unaccounted yet abundant nitrous oxide-reducing microbial community: a potential nitrous oxide sink. ISME J. 7, 417-426.

Kampschreur, M.J., Temmink, H., Kleerebezem, R., Jetten, M.S.M., Loosdrecht, M.C.M.V., 2009. Nitrous oxide emission during wastewater treatment. Water Res. 43, 4093-4103.

Kunacheva, C., Stuckey, D.C., 2014. Analytical methods for soluble microbial products (SMP) and extracellular polymers (ECP) in wastewater treatment systems: a review. Water Res. 61, 1-18.

Larson, E., Howlett, B., Jagendorf, A., 1986. Artificial reductant enhancement of the Lowry method for protein determination. Anal. Biochem. 155, 243-248.

Lei, M., Wang, S., Li, B., Cao, T., Zhang, F., Zhong, W., Peng, Y., 2016. Effect of carbon source type on intracellular stored polymers during endogenous denitritation (ED) treating landfill leachate. Water Res. 100, 405-412.

Li, P., Wu, J., Qian, H., 2016. Hydrochemical appraisal of groundwater quality for drinking and irrigation purposes and the major influencing factors: a case study in and around Hua County, China. Arab J. Geosci. 9, 1-17.

Li, X.Y., Yang, S.F., 2007. Influence of loosely bound extracellular polymeric substances (EPS) on the flocculation, sedimentation and dewaterability of activated sludge. Water Res. 41, 1022-1030.

Libing, C., Jianlong, W., 2013. Denitrification performance and biofilm characteristics using biodegradable polymers PCL as carriers and carbon source. Chemosphere 91, $1310-1316$.

Liu, W., Yang, D., Chen, W., Gu, X., 2017. High-throughput sequencing-based microbial characterization of size fractionated biomass in an anoxic anammox reactor for lowstrength wastewater at low temperatures. Bioresour. Technol. 231, 45-52.

Pan, Y., Ni, B.-J., Bond, P.L., Ye, L., Yuan, Z., 2013. Electron competition among nitrogen oxides reduction during methanol-utilizing denitrification in wastewater treatment. Water Res. 47, 3273-3281.

Park, N., Kwon, B., Kim, I., Cho, J., 2005. Biofouling potential of various NF membranes with respect to bacteria and their soluble microbial products (SMP): characterizations, flux decline, and transport parameters. J. Membrane Sci. 258, 43-54.

Phong, D.D., Jin, H., 2015. Insight into photocatalytic degradation of dissolved organic matter in UVA/ $/ \mathrm{TiO}_{2}$ systems revealed by fluorescence EEM-PARAFAC. Water Res. 87, 119-126. 
Pott, C.A., Fohrer, N., 2017. Best management practices to reduce nitrate pollution in a rural watershed in Germany. Rev. Ambiente Água 12, 888-901.

Rodgers, M., Zhan, X.M., Gallagher, B., 2003. A pilot plant study using a vertically moving biofilm process to treat municipal wastewater. Bioresour. Technol. 89, 139-143.

Saia, F.T., Souza, T.S.O., Duarte, R.T.D., Pozzi, E., Fonseca, D., Foresti, E., 2015. Microbial community in a pilot-scale bioreactor promoting anaerobic digestion and sulfurdriven denitrification for domestic sewage treatment. Bioproc. Biosyst. Eng. 39, 341-352.

Seok-Hwan, H., Woo-Nyoung, L., Hyun-Suk, O., Kyung-Min, Y., Byung-Kook, H., ChungHak, L., In-Soung, C., Sangho, L., 2007. The effects of intermittent aeration on the characteristics of bio-cake layers in a membrane bioreactor. Environ. Sci. Technol. $41,6270-6276$.

Toyofuku, M., Inaba, T., Kiyokawa, T., Obana, N., Yawata, Y., Nomura, N., 2015. Environmental factors that shape biofilm formation. Biosci. Biotech. Biochem. 80, 7-

Wang, S., Qian, K., Zhu, Y., Yi, X., Zhang, G., Du, G., Tay, J.H., Li, J., 2019. Reactivation and pilot-scale application of long-term storage denitrification biofilm based on flow cytometry. Water Res. 148, 368-377.

Wang, X.C., Shen, J.M., Chen, Z.L., Zhao, X., Xu, H., 2016. Removal of pharmaceuticals from synthetic wastewater in an aerobic granular sludge membrane bioreactor and determination of the bioreactor microbial diversity. Appl. Microbiol. Biotechnol. 100, 8213-8223.

Wang, Y., Li, P., Zuo, J., Gong, Y., Wang, S., Shi, X., Zhang, M., 2018. Inhibition by free nitrous acid (FNA) and the electron competition of nitrite in nitrous oxide $\left(\mathrm{N}_{2} \mathrm{O}\right)$ reduction during hydrogenotrophic denitrification. Chemosphere 213, 1-10.

Wang, Z., Wu, Z., Tang, S., 2009. Characterization of dissolved organic matter in a submerged membrane bioreactor by using three-dimensional excitation and emission matrix fluorescence spectroscopy. Water Res. 43, 1533-1540.

Wilderer, P.A., Jones, W.L., Dau, U., 1987. Competition in denitrification systems affecting reduction rate and accumulation of nitrite. Water Res. 21, 239-245. Wunderlin, P., Mohn, J., Joss, A., Emmenegger, L., Siegrist, H., 2012. Mechanisms of $\mathrm{N}_{2} \mathrm{O}$ production in biological wastewater treatment under nitrifying and denitrifying conditions. Water Res. 46, 1027-1037.

Xu, G., Peng, J., Feng, C., Fang, F., Chen, S., Xu, Y., Wang, X., 2015. Evaluation of simultaneous autotrophic and heterotrophic denitrification processes and bacterial

community structure analysis. Appl. Microbiol. Biotechnol. 99, 6527-6536. Yajiao W., Peng, L., Jiane, Z., Yutao, G., Sike, W., Xuchuan, S., Mengyu, Z., 2018. Inhibition by free nitrous acid (FNA) and the electron competition of nitrite in nitrous oxide $\left(\mathrm{N}_{2} \mathrm{O}\right)$ reduction during hydrogenotrophic denitrification. Chemosphere 213, $1-$ 10.

Yang, J., Zhang, X., Sun, Y., Li, A., Ma, F., 2017. Formation of soluble microbial products and their contribution as electron donors for denitrification. Chem. Eng. J. 326, $1159-1165$.

Yang, W., Zhao, Q., Lu, H., Ding, Z., Meng, L., Chen, G.H., 2016. Sulfide-driven autotrophic denitrification significantly reduces $\mathrm{N}_{2} \mathrm{O}$ emissions. Water Res. 90, 176-184. Yu,

H., Qu, F., Sun, L., Liang, H., Han, Z., Chang, H., Shao, S., Li, G., 2015. Relationship between soluble microbial products (SMP) and effluent organic matter (EfOM):

Characterized by fluorescence excitation emission matrix coupled with parallel factor analysis. Chemosphere 121, 101-109.

Zhang, H., Du, R., Cao, S., Wang, S., Peng, Y., 2019. Mechanisms and characteristics of biofilm formation via novel DEAMOX system based on sequencing biofilm batch reactor. J. Biosci. Bioeng. 127, 206-212.

Zhou, Y., Oehmen, A., Lim, M., Vadivelu, V., Ng, W.J., 2011. The role of nitrite and free nitrous acid (FNA) in wastewater treatment plants. Water Res. 45, 4672-4682.

Zhou, Y., Pijuan, M., Zeng, R.J., Yuan, Z., 2008. Free nitrous acid inhibition on nitrous oxide reduction by a denitrifying-enhanced biological phosphorus removal sludge.

Environ. Sci. Technol. 42, 8260-8265.

Zhu, L., Dai, X., Yu, Y.W., Qi, H.Y., Xu, X.Y., 2012. Role and significance of extracellular polymeric substances on the property of aerobic granule. Bioresour. Technol. 107, 46-54.

Zichao, W., Mengchun, G., Zhe, W., Zonglian, S., Qingbo, C., Changqing, S., Jian, Z., Yun, R., Ning, Y., 2013. Effect of salinity on extracellular polymeric substances of activated sludge from an anoxic-aerobic sequencing batch reactor. Chemosphere 93 2789-2795. 